10.2478/cer-2018-0011

KUNOFIWA TSAURAI*

\title{
The Impact of Remittances on Poverty Alleviation in Selected Emerging Markets
}

\begin{abstract}
The study explored the impact of remittances on poverty in selected emerging markets. On the theoretical front, the optimistic view argued that remittances inflow into the labour exporting country reduces poverty whereas the pessimistic view proponents said that remittances dependence syndrome retards both economic growth and income per capita. Separately, using two measures of poverty [the poverty headcount ratio at US \$1.90 and US \$3.10 a day (\% of population)] as dependent variables, the fixed effects approach produced results which supported the remittances led poverty reduction (optimistic) hypothesis whereas the pooled ordinary least squares (OLS) framework found that remittances inflow into the selected emerging markets led to an increase in poverty levels. The implication of the findings is that emerging markets should put in place policies that attract migrant remittances in order to reduce poverty levels. They should avoid over-reliance on remittances as that might retard economic growth and income per capita.
\end{abstract}

Keywords: remittances, poverty, emerging markets, panel data analysis

JEL: F24, I32, P2

* Ph.D., Associate Professor at the University of South Africa, Department of Finance, Risk Management and Banking, Pretoria, South Africa, e-mail: tsaurk@unisa.ac.za or kunofiwa.tsaurai@gmail.com 


\section{Introduction}

The ever-increasing volume of personal remittances flowing into developing countries and their impact in the receiving countries have attracted a lot of attention from policymakers and the research community at large. According to the Migration and Remittances Factbook (2016), developing countries received US \$144 billion in the form of international migrant remittances in the year 2016 out of the world's total of US $\$ 601$ billion that was sent by migrant labour to their home countries. The majority of economists and policymakers concur that remittances inflow not only enhances economic growth and development but also reduces poverty in the labour exporting country. Most notably, this view was supported by Adam (2011) who argued that remittances boost income levels and investment in health, education and physical assets, thereby contributing towards poverty reduction. The key question which has not been adequately addressed is: What is the remittance elasticity of poverty? In other words, how much will poverty go down in percentage terms with a given percentage rise in remittances inflow into the labour exporting country?

The aim of this paper is to study the role played by personal remittances in poverty alleviation in selected emerging markets using panel data analysis. The only research that focused on the remittance-poverty nexus in emerging and developing economies according to the author's best knowledge was done by Gaaliche and Zayati (2014) using panel data (1980-2012) analysis. The current study deviates from the study by Gaaliche and Zayati (2014) in the following ways: (1) In the past, several empirical studies investigated the impact of remittances on a specific country, but the author is not aware of any study which explicitly explored the influence of remittances on poverty exclusively in a bloc of emerging economies; (2) It used the most up to date data; (3) It compared results from two different panel data analysis methods; and (4) it used two different measures of poverty levels (poverty headcount at US $\$ 1.90$ and at US $\$ 3.10$ a day as a ratio of total population). There is a literature review in section 2, followed by remittances and poverty trends in selected emerging markets in section 3. Section 4 is a description of the methodology (empirical model and results discussion) and section 5 concludes the study.

\section{Literature review}

Consistent with Anyanwu and Erhijakpor (2010), the optimistic and pessimistic views are the two theoretical rationales that explain the relationship between remittances and poverty. According to Cattaneo (2005), the optimistic view ar- 
gues that remittances are a mechanism for economic growth and development whereas the pessimistic view says that the economy is weakened by overreliance on remittances. Anyanwu and Erhijakpor (2010) categorised the impact of remittances in the receiving countries into national, community and household-level perspectives. The household level perspective argues that household income and consumption go up and reduce poverty in response to increased international remittance inflows.

The community-level perspective argues that increased remittance flow facilitates the start-up of more small-scale enterprises, which facilitates job creation and the development of communities. The increase in household consumption inspired by remittance flow increases the demand for community-manufactured goods and services thereby promoting local development and employment creation. The national-level perspective says that remittance inflow brings more foreign currency and this enables the labour exporting country to easily meet its international payment obligations. The remittance flow increases savings and investment, thus boosting economic growth in the labour exporting country. Remittances have a multiplier effect on the economy because they are most probably spent on the consumption of domestically produced goods, consistent with Anyanwu and Erhijakpor (2010) and Ratha (2003).

Several empirical studies found results that support the remittance-led poverty reduction. A study by Waheed et al. (2013) observed that both domestic and foreign remittances decreased the level and severity of poverty in rural areas of Nigeria. The same study noted that domestic remittances, as opposed to foreign remittances, contributed more towards poverty reduction in rural areas of Nigeria. Using cross-country data analysis, Calderon et al. (2007) found that remittances led to an increase in economic growth and a reduction in poverty levels in the Caribbean and Latin American countries. In a study on 71 developing countries using panel data analysis, Adams and Page (2005) observed that remittances and migration were both instrumental in alleviating the depth, severity and level of poverty. However, a study done by Gupta et al. (2009) revealed that poverty in sub-Saharan African (SSA) countries was reduced by remittances which are stable and of a private transfer nature.

Using a two-stage multinomial logit model with data extracted from a 2005/2006 nationally representative household survey, Adams et al. (2008) investigated the impact of both internal and international remittances on poverty alleviation and inequality in Ghana. Their findings are threefold: (1) The severity, level and depth of poverty in Ghana was reduced by both internal and international remittances inflow; (2) international remittances inflow contributed to more poverty reduction in comparison to internal remittances; and (3) both types of remittances increased the inequality gap in Ghana, with international remittances contributing to a larger inequality gap than internal remittances. McKay and Deshingkar (2014) also investigated the impact of internal remittances on poverty in two Asian (Viet- 
nam and Bangladesh) and 4 African (South Africa, Rwanda, Nigeria and Uganda) countries using secondary data extracted from household surveys. Their results support the remittances-led poverty reduction hypothesis. Adams (2004) also studied the impact of internal and international (from the United States) remittances on poverty in Guatemala using data from a nationally representative household survey. The severity of poverty reduction responded to remittances inflow better than the level of poverty in Guatemala.

Craigwell et al. (2010) studied the influence of remittances on economic volatility in 95 countries using panel data analysis with data from 1970 to 2005 . Remittances were found to have had a moderating effect on economic output shocks in the countries studied. Moreover, their study noted that remittances had no influence on consumption and investment volatility. Wouterse (2010) studied the impact of remittances on poverty, social welfare and inequality in four villages of Burkina Faso using the Gini and concentration co-efficient decomposition approach. Whilst inequality was found to have been reduced by intra-African remittances, intra-continental remittances increased the inequality gap in Burkina Faso. The same study observed that intra-continental remittances played a significant positive role in lowering the level, depth and severity of poverty in Burkina Faso.

Using a literature review approach, Adams (2011) investigated the impact of international remittances on poverty, education, growth and labour supply in developing countries. The study revealed that international remittances significantly alleviated poverty and improved health levels in the developing countries. Contrary to theoretical predictions, the study noted that economic growth, education and labour supply were negatively affected by international remittances in developing countries. Slddiqui and Kemal (2006) studied the impact of a decrease in remittances and trade liberalisation shocks on poverty and welfare in Pakistan. Their study observed that the decrease in remittance flow into Pakistan led to an increase in poverty levels. Betti and Lundgren (2012) found results that support the remittance-led poverty alleviation hypothesis in the case of Tajikistan.

Using household survey data, Beyene (2014) investigated the impact of international remittances on inequality and poverty in Ethiopia. The levels, depth and severity of poverty were found to have been reduced by international remittances whilst inequality was unaffected by international remittances in Ethiopia. Serino and Kim (2011) used quantile regression analysis with panel data from 1981 to 2005 to investigate the impact of international remittances on poverty in developing countries. They found that poverty reduction induced by international remittances was more pronounced among the worst off groups in developing countries. Using household survey data, Bertoli and Marchetta (2014) studied the interrelationships between poverty, remittances and migration in Ecuador. Their study observed that migration non-significantly reduced poverty among migrant households whilst the poverty levels among the remittance receiving households was significantly reduced. 
Employing Autoregressive Distributive Lag (ARDL) with time series data from 1973 to 2007, Qayyum et al. (2008) studied the impact of remittances on poverty and economic growth in Pakistan. Economic growth and poverty reduction were positively and significantly influenced by international remittances in Pakistan. Poverty levels were reduced by international remittances in the Pakistan districts of Punjab, Sindh and Balochistan. Using the living standard survey data, Odozi et al. (2010) explored the impact of remittances on inequality and poverty in Nigeria. In line with most prior studies, they found that remittances reduced inequality and poverty levels in Nigeria during the period under study. Portes (2009) used panel data analysis with data from 1970 to 2000 to investigate the impact of remittances on poverty and inequality in 46 countries. The study observed that remittances reduced inequality and poverty levels across all the countries studied. The same study noted that the impact of remittances on poverty and inequality reduction was more felt in the poorest countries in the sample.

Using a fixed effects regression model, Viet (2008) studied the impact of foreign remittances on inequality and poverty in Vietnam. Household income and consumption in Vietnam increased in direct response to the inflow of foreign remittances. The study also found that inequality increased slightly due to foreign remittance inflows into Vietnam. On the other hand, poverty levels declined by a small percentage due to foreign remittance inflows into Vietnam. Using panel data analysis with data from 1990 to 2005, Anyanwu and Erhijakpor (2010) studied the impact of international remittances on poverty in 33 African countries. Their study observed that international remittances reduced the depth, level and severity of poverty in Africa. Hobbs and Jameson (2012) examined the influence of remittances on inequality and poverty in Nicaraguan. The study found that migrant remittances flowing from the United States led to a surge in the number of households in Nicaragua which fall under the middle-income category. Migration remittances from Costa Rica pushed up the households' consumption per capita for the poor group. Adams and Cuecuecha (2013) found that migrant remittances enabled the recipients to increase their expenditure on health, housing and education in Ghana. Moreover, remittances were found to have decreased the poverty levels in Ghana.

Other prior studies are of the view that the influence of remittances on poverty and inequality depends on the existence of certain conditions (Archaya and Leon-Gonzalez. 2012; Azam et al. (2016), Djajic (1986). Archaya and Leon-Gonzalez (2012) carried out a micro-simulation study for Nepal on the impact of remittances on poverty and inequality. Their findings are threefold: (1) remittances reduced poverty and inequality on the condition that the migration process is at a mature stage; (2) remittances widened the inequality gap overall; and (3) larger participation of the poor in the migration processes reduces both poverty and inequality in the receiving country. Azam et al. (2016) explored the influence of foreign remittances on poverty alleviation in 39 high, middle and lower income countries using the panel fully modified ordinary least squares (FMOLS) with data extract- 
ed from 1990 to 2014. Although their study noted that foreign remittances reduced poverty levels across all the countries studied, it is in high-income countries where the positive impact of foreign remittances on poverty reduction was statistically significant. Djajic (1986) investigated the impact of migration on the welfare of the remaining residents. The finding was that the remittance flow should exceed a certain minimum level for the remaining residents to benefit from migration, even without receiving the remittances themselves.

Few empirical studies support the feedback hypothesis. These include Gaaliche and Zayati (2014), Hatemi-J and Uddin (2014) and Du et al. (2005). Gaaliche and Zayati (2014) carried out a study on the remittance-poverty nexus in emerging and developing countries using panel data analysis with data ranging from 1980 to 2012 . They found that remittances and poverty reduction had a bi-directional causality relationship in emerging and developing countries. The same study noted that remittances had a weaker impact on poverty reduction whilst remittances were strongly positively influenced by poverty reduction in both developing and emerging economies. Hatemi-J and Uddin (2014) investigated the relationship between remittances and poverty reduction in Bangladesh using time series data analysis. A bi-directional causality relationship was observed in Bangladesh in the long run. The impact of remittances on poverty alleviation was weaker whilst the influence of poverty reduction on remittances was much stronger in Bangladesh.

Using household panel datasets, Du et al. (2005) found that poverty reduction and migration had a feedback effect in China's poor areas. Whilst migration boosted households' per capita income, the impact of poverty on migration in China's poor areas was positive but non-significant.

\section{Remittances and poverty trends in emerging markets}

The poverty headcount ratio at US $\$ 1.90$ per day as a percentage of GDP for the six emerging markets follows a general downward trend during the period from 1994 to 2014 (see Figure 1 in Appendix 1). For example, Brazil's poverty headcount ratio increased from $4.63 \%$ in 1994 to $5.21 \%$ in 1998 before declining from $5.21 \%$ in 1998 to $4.83 \%$ in 2002. It further decreased from $3.32 \%$ in 2006 to $2.98 \%$ in 2010 before further plummeting from $2.98 \%$ in 2010 to $1.72 \%$ in 2014 . Peru's poverty headcount ratio followed the same trend with Brazil. It increased from 4.56\% in 1994 to $6.87 \%$ in 1998 before successively going down from $6.87 \%$ in 1998 to $5.74 \%$ in 2002 , from $5.74 \%$ in 2002 to $4.09 \%$ in 2006 , and from $4.09 \%$ in 2006 to $1.30 \%$ in 2010 before further going down from $1.30 \%$ in 2010 to $0.79 \%$ in 2014 .

As for Russia, the poverty headcount ratio consistently went down during the period from 1994 to 2014 . The decline was from $0.65 \%$ in 1994 to $0.40 \%$ in 1998 , 
decreased from $0.40 \%$ in 1998 to $0.14 \%$ in 2002 before further experiencing a negative growth during the four-year subsequent period to end the year 2006 at $0.12 \%$. The poverty headcount ratio for Russia declined from $0.12 \%$ in 2006 to $0.03 \%$ in 2010 before experiencing another decrease during the subsequent four-year period end the year 2014 at $0.01 \%$. Indonesia's poverty headcount ratio increased from $8.91 \%$ to $21.57 \%$ during the period from 1994 to 1998 , before massively going down from $21.57 \%$ in 1998 to $4.3 \%$ in 2002 , then went up from $4.30 \%$ in 2002 to $6.48 \%$ in 2006 . Moreover, Indonesia's poverty headcount ratio decreased from $6.48 \%$ in 2006 to $2.91 \%$ in 2010 before further experiencing another decline during the subsequent four-year period to close the year 2014 at $1.25 \%$. On the other hand, Poland's poverty headcount ratio went down from $0.61 \%$ in 1994 to $0.01 \%$ in 1998. It remained the same during the period from 1998 to 2002 before massively recording a positive growth from $0.01 \%$ in 2002 to $0.42 \%$ in 2006 . The poverty headcount ratio of Poland declined from $0.42 \%$ in 2006 to $0.25 \%$ in 2010 before further going down during the subsequent four-year period to end the year 2014 at $0.01 \%$. Argentina's poverty headcount ratio increased from $1.45 \%$ in 1994 to $2.28 \%$ in 1998 , experiencing a massive positive growth from $2.28 \%$ in 1998 to $5.59 \%$ in 2002 before plummeting from $5.59 \%$ in 2002 to $1.91 \%$ in 2006 . Last but not least, Argentina's poverty headcount ratio went down from 1.91\% in 2006 to $0.97 \%$ in 2010 and then remained constant at that level during the period from 2010 to 2014.

Figure 2 in Appendix 1 shows that the personal remittances received as a ratio of GDP trends for the six emerging markets follows a mixed pattern during the period from 1994 to 2014. For Argentina, its personal remittances ratio declined by from $0.024 \%$ in 1994 to $0.023 \%$ in 1998 , then increased from $0.023 \%$ in 1998 to $0.211 \%$ in 2002 before going up during the subsequent four-year period to end the year 2006 at $0.23 \%$. The personal remittance received ratio for Argentina went down from $0.23 \%$ in 2006 to $0.15 \%$ in 2010 before experiencing a further decline from $0.15 \%$ in 2010 to $0.10 \%$ in 2014 . Brazil's personal remittance received ratio went down from $0.37 \%$ in 1994 to $0.19 \%$ in 1998 , increased from $0.19 \%$ in 1998 to $0.39 \%$ in 2002 and experienced a negative growth during the subsequent four-year period to end the year 2006 at $0.30 \%$ in 2006. Moreover, the personal remittance ratio for Brazil decreased from $0.30 \%$ in 2006 to $0.14 \%$ in 2010 before experiencing a further negative growth from $0.14 \%$ in 2010 to $0.11 \%$ in 2014. Indonesia's personal remittance received ratio went up from $0.25 \%$ to $1 \%$ during the period from 1994 to 1998 , declined from $1 \%$ in 1998 to $0.64 \%$ in 2002 before experiencing a massive positive growth during the subsequent four-year period to end the year 2006 at $1.57 \%$. The personal remittance ratio of Indonesia declined from $1.57 \%$ in 2006 to $0.92 \%$ in 2010 before registering a marginal positive growth during the subsequent four-year period to end 2014 at $0.96 \%$.

For Peru, the first three 4-year periods between 1998 and 2006 saw a positive growth of personal remittance ratios. The ratio of Peru's personal remittances re- 
ceived went down from $2.07 \%$ in 2006 to $1.72 \%$ in 2010 before experiencing another decrease from $1.72 \%$ in 2010 to $1.31 \%$ in 2014. Poland's personal remittance received ratio followed a similar trend to that of Peru during the entire period from 1994 to 2014. With regard to Russia, the personal remittance received ratio decreased from $1.15 \%$ in 1994 to $0.71 \%$ in 1998 , experienced a negative growth between 1998 and 2002 before registering a positive growth, from $0.27 \%$ in 2002 to $0.39 \%$ in 2006. In addition, Russia's personal remittance ratio plummeted from $0.39 \%$ in 2006 to $0.34 \%$ in 2010 before rising from $0.34 \%$ in 2010 to $0.38 \%$ in 2014 .

\section{Methodology description}

Data: The current study examined the impact of personal remittances on poverty in selected emerging markets using panel data analysis, with data ranging from 1994 to 2014. The poverty headcount ratio and personal remittances received data variables were used as the dependent and independent variable, respectively. Human capital development, GDP per capita, inflation, savings, trade openness and infrastructural development were used as control variables in the current study. The data used in this study were extracted from the World Development Indicators, International Monetary Fund, Global Financial Indicators, International Financial Statistics, United Nations Development Programmes and the United Nations Conference on Trade and Development databases.

Justification of variables and a priori expectations: In the current study, poverty is the dependent variable whereas remittance inflow is an independent variable. Inflation, infrastructural development, savings, trade openness, human capital development and GDP per capita were used as control variables, consistent with similar empirical studies. The U-shaped hypothesis founded by Kuznets (1955) argues that economic growth worsens poverty and inequality in the early stages. Once the country reaches the middle-income status, economic growth begins to contribute towards poverty alleviation and inequality reduction. Since the six emerging markets studied fall under the middle-income category, the current study expects economic growth to have a positive and significant impact on poverty reduction. According to Shahidur (2012), inflation lowers the value of people's cash holdings, their real income and the purchasing power of their money, thus subjecting them to increased poverty levels. However, the United Nations Report (2010) argued that inflation decreases real wages, thus pushing up employment levels because of reduced labour costs. The scenario also raises the possibility of workers being able to create income, generating projects for themselves, thereby contributing to a reduction in poverty levels. Inflation is therefore expected in the current study to influence poverty in a positive or negative way. 
A study done by Pradhan and Mahesh (2014) found that trade openness had a deleterious effect on poverty in developing countries. Trade openness creates new international markets for locally manufactured goods and services while also injecting new foreign manufactured goods and services into the local market. Local producers benefit in that they can now easily access foreign inputs for use in their production processes, and consumers benefit from increased variety and cheaper products, thereby raising national income and triggering poverty reduction (Pradhan \& Mahesh 2014: 2209). Trade openness is therefore expected to reduce poverty in the current study. The lack of access to credit facilities and other productive resources were identified by Okuneye (2001) as some of the reasons for the perpetuation of poverty in rural areas of Nigeria. The vicious cycle of poverty in rural areas can be broken if savings can be mobilized to meet the requirements of rural farmers and non-farmers (Azher 1995). Savings are therefore expected to reduce poverty in the six emerging economies studied.

According to Jahan and McCleery (2005), infrastructural development reduces poverty through enabling the people to have more access to better quality education, health facilities, cleaner energy sources and increased protection from the effects of natural disasters. The same study argued that infrastructural development enhances workers' productivity, there is a decline in transport costs, employment opportunities are created, and there is economic growth, all of which are ingredients necessary for lowering poverty levels. In their study on developing countries using panel data analysis, Pradhan and Mahesh (2014) observed that infrastructural development positively influenced poverty. In other words, infrastructural development contributed towards increasing poverty levels in developing countries. The current study, therefore, expects infrastructural development to positively or negatively affect poverty in the six emerging markets.

According to Chaudhry and Rehman (2009), human capital development in the form of providing better quality education which can lead to an increase in skills levels contributes towards a surge in gross national product (GNP) and poverty reduction. If people are exposed to quality education, they are most likely to secure a higher income job and access better health infrastructure, and this leads to a reduction in the number of people who live in poverty (Babatunde \& Adefabi 2005). On the other hand, Afzal et al. (2010) argued that public sector education widens the poverty gap because of its general low quality. The same study revealed that a lack of quality education is a source of child labour, thereby perpetuating poverty. It is against this background that the current study expects either a positive or a negative impact of human capital development on poverty alleviation.

Empirical model specification: Although several variables have been identified by the literature as determinants of poverty levels, the current study's main priority was to investigate the impact of remittances inflow on poverty alleviation in the selected emerging markets. The other variables, such as human capital de- 
velopment, GDP per capita, inflation, savings, trade openness and infrastructural development, were treated as explanatory variables (see Equation 1).

$$
\text { POVERTY = f(REMIT, HCD, GDPPC, INFL, SAV, OPEN, INFR) }
$$

Where REMIT, HCD, GDPPC, INFL, SAV, OPEN and INFR respectively stand for personal remittances, human capital development, economic growth, inflation, savings, trade openness and infrastructural development.

In this study, economic growth, inflation, savings, infrastructural development, trade openness, human capital development and remittances were proxied by GDP per capita, inflation consumer prices (annual \%), gross domestic savings (\% of GDP), electric power consumption ( $\mathrm{kWh}$ per capita), total imports and exports ( $\%$ of GDP), human capital development index, and personal remittances received as a ratio of GDP respectively. Two measures of poverty levels were used, and these are (1) poverty headcount ratio at US $\$ 1.90$ a day (\% of population) and (2) poverty headcount ratio at US $\$ 3.10$ a day (\% of population). Previous empirical studies on the remittance-poverty nexus informed the selection of the proxies of the variables used in the current study. The following econometric model was used to determine the impact of remittances on poverty levels in emerging economies.

$$
\begin{gathered}
\text { POVERTY }_{i, t}=\beta_{0}+\beta_{1} \text { REMIT }_{i, t}+\beta_{2} \text { HCD }_{i, t}+\beta_{3} \text { GDPPC }_{i, t}+ \\
\beta_{4} \text { INFL }_{i, t}+\beta_{5} \text { SAV }_{i, t}+\beta_{6} \text { OPEN }_{i, t}+\beta_{7} \text { INFR }_{i, t}+\mu_{i}+\varepsilon i t
\end{gathered}
$$

Where Poverty $y_{i, t}$ is the poverty headcount ratio in country $i$ at time $t, \mathrm{HCD}_{\mathrm{i}, \mathrm{t}}$ represents human capital development in country i at time t, GDPPC $_{i, t}$ is gross domestic product per capita in country $i$ at time $t, \mathrm{INFL}_{\mathrm{i}, \mathrm{t}}$ stands for inflation in country $i$ at time $t, \mathrm{SAV}_{\mathrm{i}, \mathrm{t}}$ represents savings in country $\mathrm{i}$ at time $\mathrm{t}, \mathrm{OPEN}_{\mathrm{i}, \mathrm{t}}$ is trade openness in country $i$ at time $t$ whilst INFR $_{i, t}$ represents infrastructural development in country $i$ at time t. $\beta_{0}$ is for the intercept term that captures common changes in all countries. $\beta_{1}$ up to $\beta_{7}$ stand for the coefficients of the variables used. Eit is the error term.

A negative sign of the coefficient $\beta_{1}$ indicates that remittance inflow contributed towards poverty reduction in the six emerging markets studied.

Panel root tests: Table 1 in Appendix 2 shows that not all the variables were stationary at level but, on the other hand, all the variables were stationary at first difference. The stationarity of the variables at first difference was detected at $1 \%$ level of significance in almost all the cases. The fact that the data was found to be integrated of order 1 paved way for further empirical tests.

Panel co-integration tests: Table 2 in Appendix 2 provides evidence that there are, at most, seven co-integrating equations in the relationship among the 
eight variables being studied. In other words, the Johansen Fisher panel co-integration test found that there is a long run relationship between poverty, remittances, inflation, infrastructural development, savings, trade openness, human capital development and GDP per capita.

Results and Interpretation: The study used a panel data analysis approach (fixed and pooled OLS) to explore the impact of remittance inflow on poverty levels, the results of which are found in Tables 3 and 4 (Appendix 2). Using the fixed effects approach, remittances were found to have reduced the poverty levels in the six emerging economies studied. This is in line with the optimistic view by Cattaneo (2005), which argued that remittance inflow provides a mechanism for economic growth, GDP per capita improvement and poverty alleviation. The results are also consistent with Anyanwu and Erhijakpor (2010), whose study argued that remittances influence the labour exporting country at national, community and household levels through poverty level reduction. Moreover, an increase in inflation, savings, trade openness, human capital development and GDP per capita were also observed to have had a poverty level reduction effect, consistent with theoretical predictions. Contrary to the literature, poverty levels were found to have been increased by infrastructural development. The possible explanation is that more resources channelled towards infrastructural development will be at the expense of direct economic growth promotion programmes which reduce poverty.

The pooled OLS framework revealed that personal remittances flow increased the poverty levels in the emerging markets studied. The finding is consistent with Cattaneo's (2005) pessimistic view which says that, depending on the remittances, inflow leads to a weakened rate of economic growth and income per capita. Moreover, inflation, infrastructure development, trade openness and GDP per capita reduced poverty levels, a finding which resonates with most theoretical predictions. Savings and human capital development were found to have had an exacerbating effect on poverty levels. The finding is in line with Afzal et al. (2010), whose study argued that education, if it is of low quality, can increase poverty through promoting child labour and the poverty gap. In line with the theory and most empirical predictions, remittance inflow under the fixed effects approach reduced the number of households in the poverty group in the selected emerging markets. In other words, a 1 percent increase in remittance inflow reduced the number of people in the poverty level by 23.88 percent. Moreover, inflation, savings, trade openness, human capital development and GDP per capita increase led to a reduction in the number of people trapped in the poverty level under the fixed effects model. These results resonate with theoretical predictions, as explained in sub-section 4.2 in this paper. The fixed effects model also shows that infrastructural development contributed to the increase in the number of people who fall within the poverty group.

The pooled OLS approach shows that remittance inflow into the six emerging markets resulted in the number of people in poverty going up, consistent with Cattaneo's (2005) pessimistic perspective. An increase of 1 percent in remittance 
inflow into the emerging markets studied led to an 11.26 percent increase in the number of people in poverty. The results for inflation, infrastructural development, trade openness and GDP per capita resonate with literature in that the variables contributed towards a reduction in the poverty levels in emerging markets studied. On the other hand, an increase in savings and human capital development in emerging markets studied led to an increase in poverty levels in line with Afzal et al. (2010). Contrary to theoretical predictions, the current study found that savings contributed towards an increase in poverty levels in the selected emerging markets.

\section{Conclusion}

The study explored the impact of remittances on poverty in selected emerging markets using panel data analysis. On the theoretical front, the optimistic view argued that remittances inflow into the labour exporting country reduces poverty whereas the pessimistic view proponents said that remittances inflow dependence syndrome retards economic growth and income per capita. When the poverty headcount ratio at US $\$ 1.90$ a day ( $\%$ of population) was used as a measure of poverty, the fixed effects approach produced results which supported the remittances led poverty reduction (optimistic) hypothesis. On the other hand, the pooled OLS framework found that remittances inflow into the selected emerging markets led to an increase in poverty levels, consistent with Cattaneo' (2005)s pessimistic view of the remittance-poverty nexus. When the poverty headcount ratio at US $\$ 3.10$ a day ( $\%$ of population) was used as a proxy of poverty, the fixed effects approach produced results which supported the remittance-led poverty reduction whilst the pooled OLS approach showed results that resonate with Cattaneo's (2005) pessimistic view. The implication of the findings is that emerging markets are urged to put in place policies that encourage personal remittances inflow in order to reduce poverty levels. They should also not over-rely on remittances as that might retard economic growth and income per capita, in line with Cattaneo (2005). Following an observation by Djajic (1986), future studies on the remittance-poverty nexus should investigate the minimum threshold level(s) that remittances must surpass before poverty reduction takes place in the labour exporting country. 


\section{APPENDIX 1}

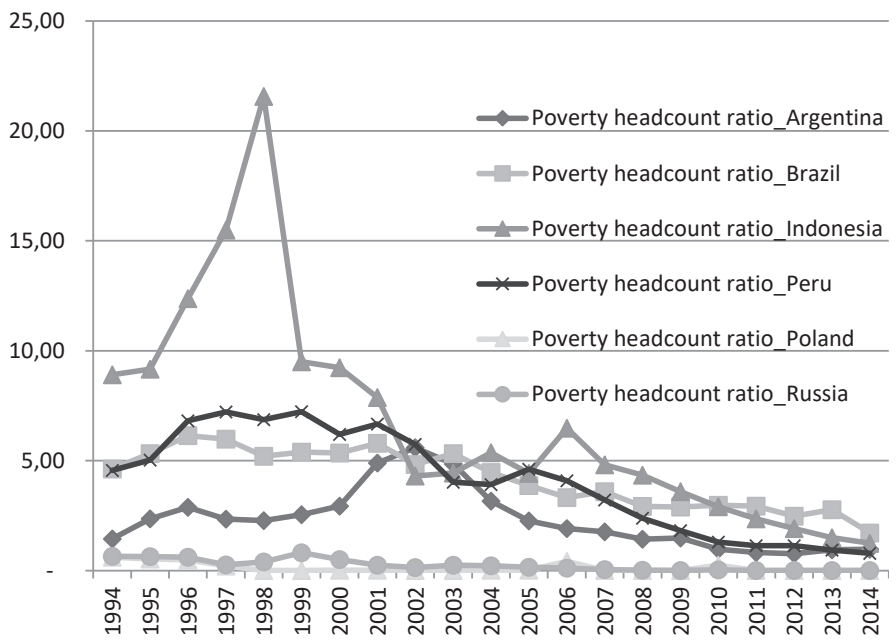

Figure 1. Poverty headcount ratio at US $\$ 1.90$ per day (\% of population) trends for six emerging markets

Source: Author's compilation.

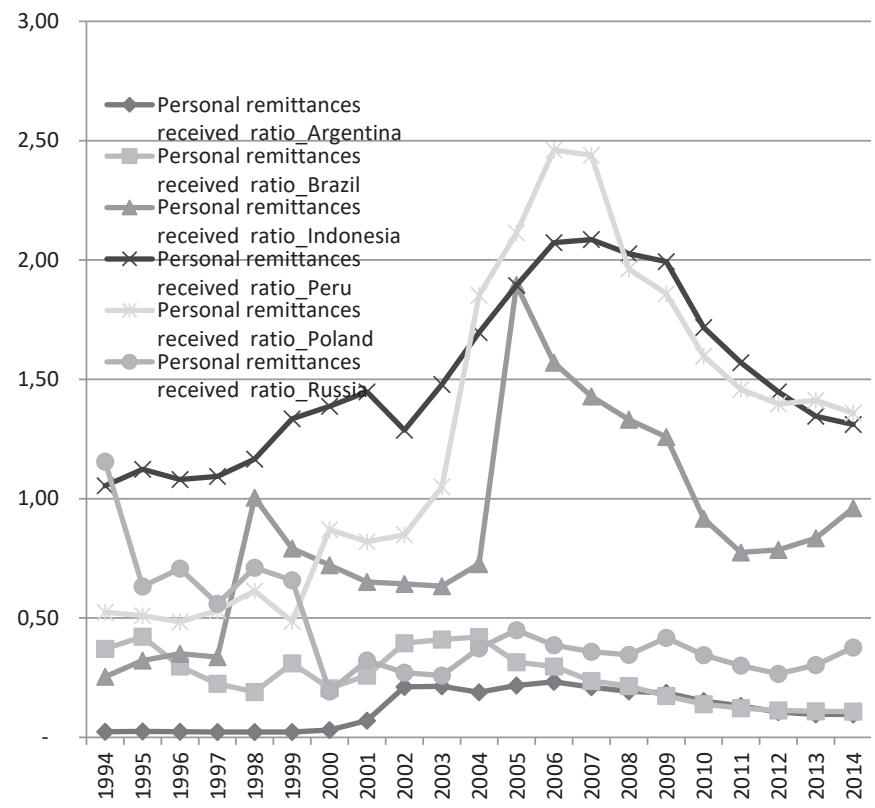

Figure 2. Personal remittances received (\% of GDP) trends for six emerging markets Source: Author's compilation. 


\section{APPENDIX 2}

Table 1. Panel root tests - Individual intercept

\begin{tabular}{|l|c|c|c|c|}
\hline \multicolumn{1}{|c|}{ Level } & LLC & IPS & ADF & PP \\
\hline L(POVERTY) & 2.1805 & 3.0108 & 7.1706 & 6.5754 \\
\hline L(REMIT) & $-1.6765^{* *}$ & -0.8357 & 15.3770 & 14.6807 \\
\hline L(HCD) & $-8.5057^{* * *}$ & $-6.5544^{* * *}$ & $59.9425^{* * *}$ & $60.1227^{* * *}$ \\
\hline L(GDPPC) & 0.6756 & 2.6483 & 2.4408 & 2.5764 \\
\hline L(INFL) & $-9.6351^{* * *}$ & $-4.7014^{* * *}$ & $68.9606^{* * *}$ & $85.4560^{* * *}$ \\
\hline L(SAV) & $-1.4922^{*}$ & $-1.5676^{*}$ & $19.8369^{*}$ & $18.6384^{*}$ \\
\hline L(OPEN) & $-2.3460^{* * *}$ & -0.6538 & 12.2346 & $20.5314^{*}$ \\
\hline L(INFR) & $-1.5935^{*}$ & 1.3702 & 7.4188 & 9.0142 \\
\hline \multicolumn{5}{|l|}{ First difference } \\
\hline L(POVERTY) & $-5.0030^{* * *}$ & $-5.8914^{* * *}$ & $54.9225^{* * *}$ & $80.1067^{* * *}$ \\
\hline L(REMIT) & $-7.6510^{* * *}$ & $-6.5258^{* * *}$ & $60.7639^{* * *}$ & $64.0428^{* * *}$ \\
\hline L(HCD) & $-10.1108^{* * *}$ & $-9.3374 * * *$ & $88.3588^{* * *}$ & $573.901^{* * *}$ \\
\hline L(GDPPC) & $-5.8949^{* * *}$ & $-5.4544^{* * *}$ & $49.7697^{* * *}$ & $49.9423^{* * *}$ \\
\hline L(INFL) & $-8.1866^{* * *}$ & $-9.2771^{* * *}$ & $88.1220^{* * *}$ & $235.081^{* * *}$ \\
\hline L(SAV) & $-6.6342^{* * *}$ & $-7.8764^{* * *}$ & $72.1493^{* * *}$ & $126.218^{* * *}$ \\
\hline L(OPEN) & $-9.3012^{* * *}$ & $-8.1915^{* * *}$ & $75.2228^{* * *}$ & $84.8836^{* * *}$ \\
\hline L(INFR) & $-2.1830^{*}$ & $-2.9017^{* * *}$ & $29.6378^{* * *}$ & $63.7282^{* * *}$ \\
\hline
\end{tabular}

Note: LLC, IPS, ADF and PP stands for Levin, Lin and Chu; Im, Pesaran and Shin; ADF Fisher Chi-Square and PP Fisher Chi-Square tests respectively. *, ** and *** denote 10\%, 5\% and 1\% levels of significance, respectively.

Source: Author's compilation from E-Views.

Table 2. Johansen Fisher Panel Co-integration test

\begin{tabular}{|l|c|c|c|c|}
\hline $\begin{array}{c}\text { Hypothesised No. } \\
\text { of CE(s) }\end{array}$ & $\begin{array}{c}\text { Fisher Statistic } \\
\text { (from trace } \\
\text { test) }\end{array}$ & Probability & $\begin{array}{c}\text { Fisher } \\
\text { Statistic (from } \\
\text { max-eigen test) }\end{array}$ & Probability \\
\hline None & 8.32 & 0.7598 & 8.32 & 0.7598 \\
\hline At most 1 & 8.32 & 0.7598 & 8.32 & 0.7598 \\
\hline At most 2 & 4.16 & 0.9804 & 59.42 & 0.0000 \\
\hline At most 3 & 0.00 & 1.0000 & 110.5 & 0.0000 \\
\hline At most 4 & 0.00 & 1.0000 & 110.5 & 0.0000 \\
\hline At most 5 & 110.5 & 0.0000 & 110.5 & 0.0000 \\
\hline At most 6 & 88.97 & 0.0000 & 65.75 & 0.0000 \\
\hline At most 7 & 53.70 & 0.0000 & 53.70 & 0.0000 \\
\hline
\end{tabular}

Source: Author's compilation from E-Views. 
Table 3. Panel regression results: Model 1

\begin{tabular}{|c|c|c|c|c|}
\hline \multirow{3}{*}{ Variable } & \multicolumn{4}{|c|}{$\begin{array}{l}\text { Dependent: Poverty (Poverty headcount ratio at US \$1.90 a day } \\
\text { (\% of population)) }\end{array}$} \\
\hline & \multicolumn{2}{|c|}{ Fixed effects } & \multicolumn{2}{|c|}{ Pooled OLS } \\
\hline & Co-efficient & t-statistic & Co-efficient & t-statistic \\
\hline REMIT & -0.1685 & -0.9347 & 0.0294 & 0.2537 \\
\hline INFL & $-0.1629^{*}$ & -1.9086 & -0.0119 & -0.1399 \\
\hline INFR & $1.5400 *$ & 1.7963 & $-1.2709 * * *$ & -6.8360 \\
\hline SAV & -0.6508 & -0.9665 & $1.8237 * * *$ & 3.8181 \\
\hline OPEN & -0.4541 & -0.6296 & $-3.4543 * * *$ & -9.4749 \\
\hline $\mathrm{HCD}$ & -1.0063 & -0.2552 & 2.3764 & 1.4648 \\
\hline GDPPC & $-2.7124 * * *$ & -6.0738 & $-0.9409 * * *$ & -5.2018 \\
\hline \multirow[t]{5}{*}{$\mathrm{C}$} & 14.6885 & 1.5120 & $25.1659 * * *$ & 13.7334 \\
\hline & \multicolumn{2}{|c|}{ R-squared 0.9383} & \multicolumn{2}{|c|}{ R-squared 0.8359} \\
\hline & \multicolumn{2}{|c|}{ Adjusted R-squared 0.9171} & \multicolumn{2}{|c|}{ Adjusted R-squared 0.8262} \\
\hline & \multicolumn{2}{|c|}{ F-statistic 44.2010} & \multicolumn{2}{|l|}{ F-statistic 85.87} \\
\hline & \multicolumn{2}{|c|}{ Prob (F-statistic) 0.0000} & \multicolumn{2}{|c|}{ Prob (F-statistic) 0.0000} \\
\hline
\end{tabular}

$* * *, * *$ and $*$ indicate $1 \%, 5 \%$ and $10 \%$ significance levels respectively

Source: Author compilation from E-Views (8).

Table 4. Panel regression results: Model 2

\begin{tabular}{|l|c|c|c|c|}
\hline \multirow{2}{*}{ Variable } & \multicolumn{4}{|c|}{$\begin{array}{c}\text { Dependent: Poverty (Poverty headcount ratio at US \$3.10 a day } \\
\text { (\% of population)) }\end{array}$} \\
\cline { 2 - 5 } & \multicolumn{3}{|c|}{ Fixed effects } & \multicolumn{2}{c|}{ Pooled OLS } \\
\cline { 2 - 5 } & Co-efficient & t-statistic & Co-efficient & t-statistic \\
\hline REMIT & $-0.2388^{*}$ & -1.7411 & 0.1126 & 1.3094 \\
\hline INFL & -0.0635 & -0.9782 & -0.0135 & -0.2150 \\
\hline INFR & $2.9070^{* * *}$ & 4.4564 & $-0.8713^{* * *}$ & -6.8360 \\
\hline SAV & -0.2093 & -0.4085 & $1.7222^{* * *}$ & 4.8545 \\
\hline OPEN & $-1.1613^{* *}$ & -2.1159 & $-2.8201^{* * *}$ & -10.4152 \\
\hline HCD & -2.2505 & -0.7500 & 1.1581 & 0.9611 \\
\hline GDPPC & $-2.4752^{* * *}$ & -7.2843 & $-1.0919^{* * *}$ & -8.1277 \\
\hline C & 4.3141 & 0.5837 & $22.2896^{* * *}$ & 16.3777 \\
\hline & R-squared 0.9490 & R-squared 0.8708 \\
\hline & Adjusted R-squared 0.9315 & Adjusted R-squared 0.8631 \\
\hline & F-statistic 54.0871 & F-statistic 113.59 \\
\hline & \multicolumn{2}{|l|}{ Prob (F-statistic) 0.0000} & Prob (F-statistic) 0.0000 \\
\hline
\end{tabular}

$* * *, * *$ and $*$ indicate $1 \%, 5 \%$ and $10 \%$ significance levels respectively

Source: Author compilation from E-Views (8). 


\section{References}

Acharya, C.P. and Leon-Gonzalez, R. (2012), The impact of remittance on poverty and inequality: A micro-simulation study for Nepal, 'National Graduate Institute for Policy Studies Discussion Paper', 11-26.

Adams, R.H. (2004), Remittances and poverty in Gautemala, 'World Bank Policy Research Working Paper', No. 3418.

Adams, R.H. and Page, J. (2005), Do international migration and remittances reduce poverty in developing countries?, 'World Development', 33(10), 1645-1669.

Adams, R.H., Cuecuecha, A. and Page, J. (2008) The impact of remittances on poverty and inequality in Ghana. The World Bank Development Prospects Group, 'Development Economics Department and African Region Policy Research Working Paper', 4732.

Adams, R.H. (2011), Evaluating the economic impact of international remittances on developing countries using household surveys: A literature review, 'The Journal of Developing Studies', 47(6), 809-828.

Adams, R.H. and Cuecuecha, A. (2013), The impact of remittances on investment and poverty in Ghana, 'World Development', 50 (October), 24-40.

Anyanwu, J.C. and Erhijakpor, A.E.O. (2010), Do international remittances affect poverty in Africa?, 'African Development Review', 22(1), 51-91.

Azam, M. Haseeb, M. Samsudin, S. (2016), The impact of foreign remittances on poverty alleviation: Global evidence, 'Interdisciplinary Approach to Economics and Sociology', 9(1), 264-21.

Azfal, M., Malik, M.E., Begum, I., Sarwar, K. and Fatima, H. (2010), Relationship among education, poverty and economic growth in Pakistan: An Econometric analysis, 'Journal of Elementary Education', 22(1), 23-45.

Azher, B. A. (1995), Rural savings: Their magnitude, determinants and mobilization, 'Pakistan Development Review', 34(4), 779-786.

Babatunde, M.A. and Adefabi, R.A. (2005), A long run relationship between education and economic growth in Nigeria: Evidence from the Johansen's co-integration approach. Paper presented at the Regional Conference in West Africa: Constraints and Opportunities, Senegal, 1-2 November 2005. Cornell University.

Bertoli, S. and Marchetta, F. (2014), Migration, remittances and poverty in Ecuador, 'The Journal of Development Studies', 50(8), 1067-1089.

Betti, G. and Lundgren, L. (2012), The impact of remittances and equivalence scales on poverty in Tajikistan, 'Central Asian Survey', 31(4), 395-408.

Beyene, B. M. (2014), The effects of international remittances on poverty and inequality in Ethiopia, 'The Journal of Development Studies', 50(10), 1380-1396.

Calderon, C., Fajnzylber, P. and Lopez, H. (2007), Remittances and growth: The role of complementary policies. Lessons from Latin America, Washington, DC: The World Bank, 33-68.

Cattaneo, C. (2005), International migration and poverty: A cross country analysis, Centro Studi Luca d'Agliano, Torino. www.dagliano.unimi.it/media/Cattaneo_Cristina.

Chaudhry, I. S. and Rahman, S. (2009), The impact of gender inequality in education on rural poverty in Pakistan: An empirical analysis, 'European Journal of Economics, Finance and Administrative Sciences', 15, 174-188. 
Craigwell, R., Jackman, M. and Moore, W. (2010), Economic volatility and remittances, 'International Journal of Development Issues', 9(1), 25-42.

Djajic, S. (1986), International migration, remittances and welfare in a dependent economy, 'Journal of Development Economics', 21(2), 229-234.

Du, Y., Park, A. and Wang, S. (2005), Migration and rural poverty in China, 'Journal of Comparative Economics', 33(4), 688-709.

Gaaliche, M. and Zayati, M. (2014), The causal relationship between remittances and poverty reduction in developing country: Using a non-stationary dynamic panel data, 'Atlantic Review of Economics', 1(14), 1-12.

Gupta, S., Pattillo, C. and Wagh, S. (2009), Impact of remittances on poverty and financial development in Sub-Saharan Africa, 'World Development', 37(1), 104-115.

Hatemi-J,A. and Uddin, G.S. (2014), On the causal nexus of remittances and poverty reduction in Bangladesh, 'Applied Economics', 46(4), 374-382.

Hobbs, A.W. and Jameson, K.P. (2012), Measuring the effect of bi-directional migration remittances on poverty and inequality in Nicaragua, 'Applied Economics', 44(19), 2451-2460.

Im, K. S., Pesaran, M.H. and Shin, Y. (2003), Testing unit roots in heterogeneous panels, 'Journal of Econometrics', 115(1), 53-74.

Jahan, S. and McCleery, R. (2005), Making infrastructure work for the poor: Synthesis report of four country studies - Bangladesh, Senegal, Thailand and Zambia. New York: UNDP.

Kuznets, S. (1955), Economic growth and income inequality, 'American Economic Review', (March), 1-28.

Levin, A., Lin, C.F. and Chu, C. S.J. (2002), Unit root tests in panel data: Asymptotic and finite-sample properties, 'Journal of Econometrics', 108(1), 1-24.

McKay, A. and Deshingkar, P. (2014). Internal remittances and poverty: Further evidence from Africa and Asia, Migrating out of poverty Research Programme Consortium Working Paper 12.

Migrant and Remittances (2016). Produced by World Bank Group's Global Knowledge Partnership on Migration and Development. Third Edition.

Odozi, J.C., Awoyemi, T. T. and Omonona, B. T. (2010), Household poverty and inequality: The implication of migrants' remittances in Nigeria, 'Journal of Economic Policy Reform', 13(2), 191-199.

Okuneye, P.A. (2001), Rural poverty assessment and control in Africa. An invited specialisation course paper presented at the United Nations IDEP, Dakar Senegal, June 19-22.

Portes, L.S.V. (2009), Remittances, poverty and inequality, 'Journal of Economic Development', 34(1), 127-140.

Pradhan, B.K. and Mahesh, M. (2014), Impact of trade openness on poverty: A panel data analysis of a set of developing countries, 'Economic Bulletin', 34(4), 2208-2219.

Qayyum, A. Javid, M. and Arif, U. (2008). Impact of remittances on economic growth and poverty: Evidence from Pakistan, 'Munich Personal RePEc Archive Paper', No. 222941.

Ratha, D. (2003). Workers' remittances: An important and stable source of external development finance. In Global Development Finance 2003, Striving for development and finance. The World Bank, Washington, DC. 
Serino, M.N. and Kim, D. (2011), How do international remittances affect poverty in developing countries?, 'Journal of Economic Development', 36(4), 17-40.

Shahidur, S.T (2012), The effect of inflation on poverty in developing countries: A panel data analysis, Master of Arts Dissertation with Texas Tech University. Unpublished, 1-56.

Slddiqui, R. and Kemal, A.R. (2006), Remittances, trade liberalisation and poverty in Pakistan: The role of excluded variables in poverty change analysis, 'The Pakistan Development Review', 45(3), 383-415.

United Nations (2010). Rethinking poverty, Report on the World Social Situation, United Nations, New York.

Viet, C.N. (2008), Do foreign remittances matter to poverty and inequality? Evidence from Vietnam, 'Economic Bulletin', 15(1), 1-11.

Waheed, O. O., Timothy, A. T., Adebayo, S. M. and Ayodele, O. (2013), Effects of remittances on poverty among rural households in Nigeria, 'European Journal of Sustainable Development', 2(4), 263-284.

Wouterse, F. (2010), Remittances, poverty, inequality and welfare: Evidence from the Central Plateau of Burkina Faso, 'The Journal of Development Studies', 46(4), 771-789.

\section{Streszczenie}

\section{WPLYW PRZEKAZÓW PIENIĘŻNYCH NA ZMNIEJSZANIE UBÓSTWA NA WYBRANYCH RYNKACH WSCHODZĄCYCH}

W artykule przedstawiono wyniki analizy wpływu przekazów pieniężnych na poziom ubóstwa na wybranych rynkach wschodzacych. W rozważaniach teoretycznych zwolennicy optymistycznego podejścia uważaja, że napływ środków pieniężnych do kraju eksportującego pracę zmniejsza ubóstwo, podczas gdy zwolennicy podejścia pesymistycznego twierdza, że syndrom uzależnienia od przekazów pieniężnych ogranicza zarówno wzrost gospodarczy, jak i dochód per capita. Przy zastosowaniu dwóch miar ubóstwa [wskaźnik ubóstwa na poziomie 1,90 USD i 3,10 USD dziennie (\% populacji)] jako zmiennych zależnych, podejście oparte na statych efektach dało wyniki potwierdzajace teze, iż przekazy pieniężne prowadza do ograniczenia ubóstwa (potwierdzenie hipotezy optymistycznej), podczas gdy przy użyciu metody pooled ordinary least squares (OLS) wykazano, że naptyw środków w postaci przekazów pieniężnych na wybrane rynki wschodzace doprowadzit do wzrostu poziomu ubóstwa. Z powyższych ustaleń wnika wniosek, że rynki wschodzace powinny wprowadzić politykę przyciagania przekazów migracyjnych w celu zmniejszenia poziomu ubóstwa. Powinny unikać natomiast nadmiernego polegania na przekazach pieniężnych, ponieważ może to opóźnić wzrost gospodarczy i ograniczyć dochód per capita.

Slowa kluczowe: przekazy pieniężne; ubóstwo; rynki wschodzace; analiza danych panelowych 